\title{
Antimicrobial stewardship: Assessment of knowledge, awareness of antimicrobial resistance and appropriate antibiotic use among healthcare students in a Nigerian University
}

\author{
Wuraola Akande-Sholabi* and Amen T. Ajamu
}

\begin{abstract}
Background: Inappropriate use of antibiotics is a major cause of antimicrobial resistance (AMR). Inadequate knowledge about AMR among healthcare students could affect their practice of antimicrobial stewardship as future healthcare professionals. This study aims to assess the use of antibiotics and knowledge of AMR among future healthcare professionals of a Nigerian University.

Methods: Respondents' knowledge of antimicrobial resistance, use of antibiotics, and source of antibiotics in the past 12 months was explored using a self-administered questionnaire. Multivariate analyses were used to evaluate the relationship between specific variables and respondents' knowledge.

Results: Of the 939 questionnaires administered to the students, 866 were filled given a response rate of $92.2 \%$. A total of $(765 ; 88.3 \%)$ of the respondents were aware that antimicrobial resistance makes it harder to eliminate the infection from the body as existing drugs become less effective. In all 824, (95.2\%) of the respondents had use antibiotics in the past 12 months. The use of antibiotics to treat malaria was self-reported by $(175 ; 21.2 \%)$. About half $(432 ; 52.4 \%)$ purchased the antibiotics from community pharmacies, while others obtained their antibiotics from the hospitals $(192 ; 23.3 \%)$, patent medicine stores $(150 ; 18.2 \%)$, and friends and family $(50 ; 6.1 \%)$ in the last 12 months. In all 506, (58.4\%) had good knowledge of antimicrobial resistance. Logistic regression shows that students in 3rd to 6th year 9.29 [AOR=9.29, $95 \%$ Cl: (3.7-22.96)], had greater knowledge of antimicrobial resistance.

Conclusions: The healthcare students demonstrated a moderate knowledge of AMR. This underscores the need to adopt several educational tactics to introduce the concepts of AMR to the students and ensure there are strict policies to regulate the flow of antibiotics.
\end{abstract}

Keywords: Antibiotic use, Antimicrobial resistance, Antimicrobial stewardship, Healthcare students, Knowledge

\footnotetext{
*Correspondence: wuradol@gmail.com

Department of Clinical Pharmacy and Pharmacy Administration, Faculty of

Pharmacy, University of Ibadan, Ibadan, Nigeria
}

(c) The Author(s). 2021 Open Access This article is licensed under a Creative Commons Attribution 4.0 International License, which permits use, sharing, adaptation, distribution and reproduction in any medium or format, as long as you give appropriate credit to the original author(s) and the source, provide a link to the Creative Commons licence, and indicate if changes were made. The images or other third party material in this article are included in the article's Creative Commons licence, unless indicated otherwise in a credit line to the material. If material is not included in the article's Creative Commons licence and your intended use is not permitted by statutory regulation or exceeds the permitted use, you will need to obtain permission directly from the copyright holder. To view a copy of this licence, visit http://creativecommons.org/licenses/by/4.0/ The Creative Commons Public Domain Dedication waiver (http://creativecommons.org/publicdomain/zero/1.0/) applies to the data made available in this article, unless otherwise stated in a credit line to the data. 


\section{Introduction}

The advent of antibiotics indicated that previously untreatable medical conditions became treatable, surgeries became largely successful, and the entire medical practice experience has not been the usual since then [1]. Unfortunately, this admirable phase of medical practice is being threatened by the inappropriate use of antibiotics, leading to antimicrobial resistance (AMR). It has been reported that inappropriate use of antibiotics is estimated to be $20-50 \%$ in Nigeria [2]. The term "inappropriate use" comprises the use of antibiotics to treat all forms of infections, incomplete dosage regimen during treatment, and sharing of antibiotics with others without prescription by a physician [3]. Furthermore, antimicrobial resistance (AMR) occurs naturally when microorganisms (such as bacteria, fungi, viruses, and parasites) can not be killed by an antimicrobial drug to which they were hitherto sensitive, usually due to genetic mutations [4].

Globally, antimicrobial resistance is a foremost public health challenge, particularly in developing countries. Misuse of antimicrobials is assisted in developing countries by their availability over the counter, without a prescription, and through unregulated supply chains $[5,6]$. AMR leads to decreased medication efficiency, complication during treatment of patients, or an increase in management cost. There is, therefore, an urgent need to tackle antimicrobial resistance in developing countries specifically in Africa because it is being ignored and yet vastly associated with high morbidity and mortality [7].

Healthcare students as future prescribers and dispensers of antimicrobials have a crucial role in reducing the inappropriate use of antibiotics; there has been a rising volume of research reports in the literature concentrated on exploring the knowledge, attitude, and practice of students towards antibiotics use. Previous studies conducted among health care students showed an existing gap between knowledge and practice and reported the need for educational interventions to improve knowledge and awareness of antibiotic stewardship among healthcare students [8,9]. It is worthy to note that, the way an individual perceives an idea may also affect his/her behavior on an issue, thus generating behavioral and contextual barriers. Evidence suggests that strategic actions such as antimicrobial stewardship must be enforced. Therefore, improving the knowledge of healthcare students especially pharmacy students is crucial in the fight against AMR. Well-educated pharmacists can contribute to the decrease of irrational use of antimicrobials. Thus, making the pharmacist's role in the healthcare system of developing countries significant in the global battle against AMR [10].

Efforts channeled towards decreasing the occurrence of antimicrobial resistance are not essentially about restricting access to an antibiotic, but to ensure that antibiotics are used appropriately. This means that accurate and effective antibiotic stewardship should be directed at rational use and not just access restriction. Moreover, the World Health Organization reports encourage the training of healthcare students on appropriate antimicrobial prescribing and an introduction of the concepts of antimicrobial stewardship into the undergraduate programme [11].

It is worthy of note that in Nigeria, most of the previous studies on inappropriate use of antibiotics and knowledge on antimicrobial resistance were focused on general populations $[12,13]$, with a paucity of information on healthcare students. Thus, this study aims to evaluate the use of antibiotics and knowledge of antimicrobial resistance among future healthcare professionals at a Nigerian University.

\section{Method \\ Study design and settings}

This is a university-based cross-sectional study using a self-administered questionnaire. It was conducted among undergraduate students of the Faculty of Pharmacy, Department of Nursing, and Department of Medicine and Surgery, between August and November 2019. Presently in Nigeria, the Bachelor of Pharmacy and Bachelor of Nursing degree are a 5-year programme, while the Bachelor of Medicine and Surgery degree is a 6-year programme. Eligible participants were registered undergraduate Pharmacy, Nursing, and Medicine and Surgery students for the 2018/2019 academic session and consented to partake in the study. Students that were absent and non-consenting were excluded from the study.

\section{Sample size determination}

Based on the population of 1521 registered students obtained from the faculty management, Pharmacy (360), Medicine and Surgery (881), and Nursing (280) the confidence level was set at $95 \%$ and the alpha error at $5 \%$, arriving at a sample size of 316 using Yamane's formula [14]. The target sample size arrived after calculation using Yamane's formula was Pharmacy (75), Medicine and Surgery (183), and Nursing (58). Additionally, to cater for the possibility of a low response rate, which is not uncommon among students, an attrition rate close to $200 \%$ was used.

\section{Sampling and data collection procedure}

At each level in each faculty, a compulsory course for the students was identified. The study respondents were consecutively approached shortly after the mandatory course. The researcher informed the participants of the study objectives. Questionnaires were disseminated to all 
consenting healthcare students physically and recovered within 20-25 min. Study participation was voluntary and the students were informed of the possibility of withdrawing from the study anytime. Response anonymity and confidentiality were reiterated to the respondents. Measures were put in place to prevent multiple filling of the questionnaire by the respondents.

\section{Data collection instrument}

The questionnaire used for the study was designed by the researchers after a thorough review of similar studies $[7,8]$, as well as utilizing researchers' proficiency. The questionnaire comprised three sections and a total of 20 questions. Section A comprised of demographic characteristics of the students. Section B consists of questions on participants' use of antibiotics, frequency of antibiotic use, and source of antibiotics in the past 12 months. Section $C$ comprises of 10 -item questions with a 5 -point Likert scale response option ranging from strongly agree (5) to strongly disagree (1) to evaluate students' knowledge of antimicrobial resistance. The overall score for the knowledge questions was categorized into 'good' and 'poor' depending on respondents' scores in each domain. For the 10-item statements on knowledge with a 5-point Likert scale response, a total score of at least $40(\geq 80 \%)$ out of the maximum obtainable score of 50 was categorized as 'good' knowledge, while a knowledge score $<40$ $(<80 \%)$ was categorized as 'poor' knowledge. The binary categorization of knowledge scores was adapted from Bloom's cut-off criteria and other similar studies [15-17]. There were four negatively worded knowledge questions (items $2,3,9,10$ ), these questions were reversed scored.

\section{Pretest and content validation}

Content validity of the questionnaire was conducted by one pharmacist and one medical doctor in academia, to establish the inclusiveness of question-items when compared with the objectives of the study. Thereafter, face validity was established by administering the questionnaire to thirty students from the Pharmacy, Nursing, and Medicine and Surgery Department to ascertain the ease of comprehension of questions or statements in the questionnaire. These students were exempted from the main study and the response from the students led to some modifications including reformatting some questions to eliminate response ambiguity.

\section{Statistical analysis}

Data were coded, cleaned, and analyzed using the IBM Statistical Package for Social Sciences (version 23). Descriptive statistics such as frequency counts and percentages, mean, and standard deviation were used to summarize and present the result. Prior to the analysis, all negatively worded items in the knowledge questions were reversed scored. Chi-square test was used to investigate the association between relevant demographic characteristics and the level of knowledge on antimicrobial resistance and proper handling of antibiotics. Logistic regression analysis was used to explore relationships between significant variables and knowledge of antimicrobial resistance. The level of significance was set at $P<0.05$.

\section{Ethics approval}

Ethics approval for the study was obtained from the joint University of Ibadan/University College Hospital Institution Review Board with approval number UI/EC/ 19/0403.

Table 1 Demographic characteristics of healthcare students $(n=866)$

\begin{tabular}{|c|c|c|}
\hline Variable & Number of students & Percentage \\
\hline \multicolumn{3}{|l|}{ Age } \\
\hline$\leq 20$ & 405 & 46.8 \\
\hline $21-29$ & 453 & 52.3 \\
\hline$\geq 30$ & 8 & 0.9 \\
\hline \multicolumn{3}{|l|}{ Gender } \\
\hline Male & 419 & 48.4 \\
\hline Female & 447 & 51.6 \\
\hline \multicolumn{3}{|c|}{ Department and level of Study } \\
\hline \multicolumn{3}{|l|}{$\begin{array}{l}\text { Nursing } \\
n=155\end{array}$} \\
\hline Year 1 & 32 & 20.6 \\
\hline Year 2 & 28 & 18.1 \\
\hline Year 3 & 39 & 25.2 \\
\hline Year 4 & 35 & 22.6 \\
\hline Year 5 & 21 & 13.5 \\
\hline \multicolumn{3}{|c|}{$\begin{array}{l}\text { Pharmacy } \\
n=275\end{array}$} \\
\hline Year 1 & 46 & 16.7 \\
\hline Year 2 & 22 & 8.0 \\
\hline Year 3 & 44 & 16.0 \\
\hline Year 4 & 88 & 32.0 \\
\hline Year 5 & 75 & 27.3 \\
\hline \multicolumn{3}{|c|}{$\begin{array}{l}\text { Medicine and surgery } \\
\boldsymbol{n}=436\end{array}$} \\
\hline Year 1 & 47 & 10.8 \\
\hline Year 2 & 79 & 18.1 \\
\hline Year 3 & 104 & 23.9 \\
\hline Year 4 & 64 & 14.7 \\
\hline Year 5 & 88 & 20.2 \\
\hline Year 6 & 54 & 12.4 \\
\hline
\end{tabular}




\section{Results}

Table 1 shows details on the demographic characteristics of the study population. Of the 939 questionnaires administered to the students, 866 were filled given a response rate of $92.2 \%$. Females were $(447 ; 51.6 \%)$ and males were $(419 ; 48.4 \%)$. The half of respondents were medical students $(436 ; 50.3 \%)$ while nursing was the least represented $(155 ; 17.9 \%)$.

The assessment of respondents' knowledge of antimicrobial resistance is shown in Table 2. Overall, a total of 506 (58.4\%) had good knowledge of antimicrobial resistance and proper handling of antibiotics.

The classification of antibiotic use showed malaria (175; $16.9 \%)$, cough $(168 ; 16.3 \%)$, and sore throat (164; $15.9 \%)$ were the commonest ailments antibiotic was used for, while amoxicillin (265; $32.2 \%$ ), ciprofloxacin $(166 ; 17.2 \%)$ and metronidazole (157; $16.2 \%)$ were the most common antibiotics used according to the frequency of use. More than half of the respondents $(432 ; 52.4 \%)$ purchased their antibiotics from the community pharmacies, others obtained their antibiotics from hospitals $(192 ; 23.3 \%)$ and patent medicine vendors $(150 ; 18.2 \%)$. Overall, a total of 824, (95.2\%) of respondents had received antibiotics in the last 12 months. Of the 824 students that self-reported the use of antibiotics, the majority 663, (76.6\%) used it only when needed and $(104 ; 29.4 \%)$ got drug information from patient information leaflets in the drugs Details in Table 3.
The multivariate analysis for the variables that were significantly associated with good knowledge of antimicrobial resistance at the bivariate level showed that students in 3rd year $[\mathrm{AOR}=1.75 ; 95 \%$ CI 1.09-2.80], 4th year $[\mathrm{AOR}=5.47 ; 95 \%$ CI 3.13-9.55], 5th year $[\mathrm{AOR}=5.42 ; 95 \% \mathrm{CI} 2.94-9.97]$, and 6th year $[\mathrm{AOR}=$ 9.29; $95 \%$ CI 3.7-22.96], demonstrated greater knowledge of antimicrobial resistance $(p<0.05)$ as shown in Table 4.

\section{Discussion}

This study aimed to evaluate the use of antibiotics and knowledge of antimicrobial resistance among future healthcare professionals in a Nigerian University. Appropriate use of antimicrobials is central to curbing the incidence of antimicrobial resistance (AMR), which can be accomplished by changing prescribers' behavior and knowledge [11]. In this study, it was shown that about $41.6 \%$ of the participants demonstrated poor knowledge about antimicrobial resistance. This is lower compared to other studies reported in Portugal, Trinidad and Tobago, which reported a better understanding of antimicrobial resistance among the study participants $[18,19]$. The difference in antimicrobial stewardship across countries might be attributed to the variations in demographic characteristics, questions used in the survey, and socioeconomic factors of the respondents $[18,19]$.

Table 2 Respondents' knowledge on antimicrobial resistance $(n=866)$

\begin{tabular}{|c|c|c|c|c|c|c|}
\hline & \multirow[t]{2}{*}{ Variable } & SA & A & \multirow{2}{*}{ U } & \multirow{2}{*}{$\begin{array}{l}\mathrm{D} \\
\mathrm{n}(\%)\end{array}$} & \multirow{2}{*}{$\begin{array}{l}\text { SD } \\
\text { n (\%) }\end{array}$} \\
\hline & & n (\%) & n (\%) & & & \\
\hline 1. & $\begin{array}{l}\text { Antimicrobial resistance is the ability of microbes to grow in the presence of a } \\
\text { chemical (drug) that would normally kill them or limit their growth }\end{array}$ & $407(47.0)$ & $381(44.0)$ & $53(6.1)$ & $13(1.5)$ & $12(1.4)$ \\
\hline 2. & $\begin{array}{l}\text { It is not necessary to complete the regimen of an antibiotic to reduce the } \\
\text { chances of the occurrence of bacteria resistance to drug }\end{array}$ & $32(3.7)$ & $69(8.0)$ & $83(9.6)$ & 282(32.6) & $400(46.2)$ \\
\hline 3. & $\begin{array}{l}\text { It is not necessary to use the correct dose of an antibiotic to reduce the chances } \\
\text { of the occurrence of bacteria resistance to drug }\end{array}$ & $25(2.9)$ & $52(6.0)$ & $87(10.0)$ & 284(32.8) & $418(48.3)$ \\
\hline 4. & Antimicrobial resistance cause death & $213(24.6)$ & $337(38.9)$ & $225(26.0)$ & $58(6.7)$ & $33(3.8)$ \\
\hline 5. & Improper self-medication can cause antimicrobial resistance & $346(40.0)$ & $405(46.8)$ & $85(9.8)$ & $15(1.7)$ & $15(1.7)$ \\
\hline 6. & Antimicrobial resistance affects all age groups & $334(38.6)$ & $405(46.8)$ & 102(11.8) & $18(2.1)$ & $7(0.8)$ \\
\hline 7. & $\begin{array}{l}\text { Antimicrobial resistance makes it harder to eliminate infections from the body } \\
\text { as existing drugs become less effective }\end{array}$ & $401(46.3)$ & $364(42.0)$ & $77(8.9)$ & $16(1.8)$ & $8(0.9)$ \\
\hline 8. & $\begin{array}{l}\text { Antimicrobial resistance can lead to spread of infections due to ineffectiveness } \\
\text { of standard treatment }\end{array}$ & $347(40.1)$ & $409(47.2)$ & $87(10.0)$ & $14(1.6)$ & $9(1.0)$ \\
\hline 9. & Antibiotics will improve the outcome of the treatment of common cold & $92(10.6)$ & $260(30.0)$ & $241(27.8)$ & $166(19.2)$ & $107(12.4)$ \\
\hline \multirow[t]{4}{*}{10.} & Antibiotics will improve the outcome of the treatment of uncomplicated malaria & $62(7.2)$ & $176(20.3)$ & 273(31.5) & 202(23.3) & $153(17.7)$ \\
\hline & Cut-off score & \multicolumn{2}{|c|}{ Frequency $\mathrm{n}(\%)$} & emark & & \\
\hline & $<8$ (i.e., $<80 \%$ ) & \multicolumn{2}{|c|}{$360(41.6)$} & \multicolumn{2}{|c|}{ Poor knowledge } & \\
\hline & $\geq 8$ (i.e., $\geq 80 \%$ ) & \multicolumn{2}{|c|}{$506(58.4)$} & \multicolumn{2}{|c|}{ Good knowledge } & \\
\hline
\end{tabular}

Maximum obtainable score $=50 ; \%$ individual score $=$ score obtained by an individual $\div$ by total obtainable score $x 100$. Strongly agree $(S A)=5$, Agree $(A)=4$, Undecided $(U)=3$, Disagree $(D)=2$, Strongly disagree $(S D)=1$. Items $2,3,9,10$, were negatively worded know questions, these questions were reversed scored. 
Table 3 Respondents' classification of the use of antibiotics, frequency of antibiotic use, and source of antibiotics in the last 12 months $(n=824)$

\begin{tabular}{|c|c|c|}
\hline Variable & Number of students & Percentage \\
\hline 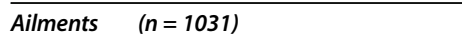 & & \\
\hline $\begin{array}{l}\text { Malaria } \\
\text { Cough }\end{array}$ & $\begin{array}{l}175 \\
168\end{array}$ & $\begin{array}{l}16.9 \\
16.3\end{array}$ \\
\hline Sore throat & 164 & 15.9 \\
\hline Common cold & 125 & 12.1 \\
\hline Typhoid & 107 & 10.4 \\
\hline Genitourinary infections & 96 & 9.3 \\
\hline $\begin{array}{l}\text { Diarrhea } \\
\text { Diseases of the skin }\end{array}$ & $\begin{array}{l}88 \\
62\end{array}$ & $\begin{array}{l}8.5 \\
6.0\end{array}$ \\
\hline Ulcer & 29 & 2.8 \\
\hline Sexually Transmitted diseases & 17 & 1.8 \\
\hline Antibiotics $\quad(n=967)$ & & \\
\hline $\begin{array}{l}\text { Amoxicillin } \\
\text { Ciprofloxacin } \\
\text { Metronidazole }\end{array}$ & $\begin{array}{l}265 \\
166 \\
157\end{array}$ & $\begin{array}{l}27.5 \\
17.2 \\
16.2\end{array}$ \\
\hline Amoxicillin + clavulanic acid & 136 & 14.0 \\
\hline $\begin{array}{l}\text { Tetracycline } \\
\text { Erythromycin }\end{array}$ & $\begin{array}{l}95 \\
63\end{array}$ & $\begin{array}{l}9.8 \\
6.5\end{array}$ \\
\hline Penicillin & 37 & 3.8 \\
\hline Doxycycline & 30 & 3.1 \\
\hline Azithromycin & 18 & 1.9 \\
\hline \multicolumn{3}{|l|}{ Source of Antibiotic $(n=824)$} \\
\hline Community pharmacy & 432 & 52.4 \\
\hline Hospital & 192 & 23.3 \\
\hline Patent Medicine Vendor & 150 & 18.2 \\
\hline Friends and family & 50 & 6.1 \\
\hline Frequency of use of Antibiotic $\quad(n=866)$ & & \\
\hline When needed & 663 & 76.6 \\
\hline Once yearly & 44 & 5.1 \\
\hline Once every 3 months & 40 & 4.6 \\
\hline Monthly & 22 & 2.5 \\
\hline Weekly & 55 & 6.4 \\
\hline Never & 42 & 4.8 \\
\hline \multicolumn{3}{|c|}{$\begin{array}{l}\text { Source of drug information about dosage and duration of use of antibiotic } \\
(n=354)\end{array}$} \\
\hline Patient information leaflet in the drug & 104 & 29.4 \\
\hline Family and friends & 67 & 18.9 \\
\hline Curriculum/classroom & 60 & 16.9 \\
\hline Textbook & 54 & 15.3 \\
\hline Internet (Medscape, google and others) & 41 & 11.6 \\
\hline Print media (newspaper and Magazines) & 15 & 4.2 \\
\hline Social media & 13 & 3.7 \\
\hline
\end{tabular}

$\pitchfork=$ multiple responses
It is apparent that among the students who appear to be knowledgeable on antimicrobial resistance, the appropriate use of antibiotics is not revealed in their regular life as documented in this study. This is evident from the proportion of respondents who used antibiotics for the management of malaria, cough, sore throat, and the common cold. This inappropriate use of antibiotics might be due to a lack of information on antimicrobial use. A study conducted in Nigeria reported antibiotics to be among the top three medications used for selfmedication among undergraduate healthcare students, who believed that they have acquired the requisite medical knowledge of what to use for a particular condition treated [20].

However, the majority of the participants showed an imperative characteristic to acquire their antibiotics from either the community pharmacy or hospital and use the antibiotics only when needed. They were also aware of the fact that antimicrobial resistance makes it harder to eliminate the infection from the body as existing drugs become less effective. Surprisingly, about a fifth of the respondents purchased their antibiotics from proprietary and patent medicine vendors (PPMV). In Nigeria, PPMVs are defined as "a person without formal training in pharmacy who sells orthodox pharmaceutical products on a retail basis for profit" [21]. Regulations permit PPMVs to sell a limited number of pre-packaged, overthe-counter medicines and medical products but prohibit them from selling prescription medications (including antibiotics) or conducting invasive medical procedures (e.g. injections) [21]. Even though the sale of antibiotics is outside PPMVs' current scope of practice, some respondents were able to purchase this medication from them, this might be due to lack of strict and enforced laws and regulations on how antibiotics are prescribed and dispensed in retail pharmacies in Nigeria and among these vendors. It is worthy to note that the purchase of antibiotics without a prescription is common in Nigeria. Moreover, future healthcare professionals should be aware of the legal scope of practice of PPMVs allowed by the law. This result is similar to findings in Nigeria where $60 \%$ of sick children received antibiotics from PPMVs [22]. These results suggest support courses either in the curriculum or as a workshop/seminar could be introduced to educate the students at the university level on inappropriate use and purchase of antibiotics and promote awareness of antimicrobial stewardship among future healthcare professionals. In addition, there is a possibility of overprescribing antibiotics without the performance of antimicrobial susceptibility test in retail pharmacies and among the vendors. It is important to emphasize the need for performing the antimicrobial susceptibility tests before prescribing antibiotics. Thus, medical students should be aware that 
Table 4 Predictors of Knowledge of Antimicrobial Resistance among healthcare students $(n=866)$

\begin{tabular}{|c|c|c|c|c|c|c|}
\hline \multirow[t]{3}{*}{ Variables } & \multicolumn{2}{|c|}{ Knowledge on Antimicrobial Resistance } & \multicolumn{2}{|c|}{ Unadjusted Odd ratio } & \multicolumn{2}{|c|}{ Adjusted Odd ratio } \\
\hline & \multirow[b]{2}{*}{$\begin{array}{l}\text { Good } \\
\text { n (\%) }\end{array}$} & \multirow[b]{2}{*}{$\begin{array}{l}\text { Poor } \\
\text { n (\%) }\end{array}$} & OR $(95 \% \mathrm{Cl})$ & p-value & AOR $(95 \% \mathrm{Cl})$ & $p$-value \\
\hline & & & & & & \\
\hline \multicolumn{7}{|l|}{ Gender } \\
\hline Male & $242(57.8)$ & $177(42.2)$ & 1 & & & \\
\hline Female & $264(59.1)$ & $183(40.9)$ & $1.05(0.80-1.38)$ & 0697 & $1.28(0.93-1.76)$ & 0.117 \\
\hline \multicolumn{7}{|l|}{ Age-group (years) } \\
\hline$\leq 20$ (ref) & $200(49.4)$ & 205 (5.6) & 1 & & & \\
\hline $21-29$ & $299(66.0)$ & $154(34.0)$ & $1.99(1.51-2.62)$ & $0.001^{*}$ & $0.78(0.51-1.19)$ & 0.261 \\
\hline$\geq 30$ & $7(87.5)$ & $1(12.5)$ & $7.17(0.87-58.84)$ & 0.006 & $2.47(0.28-21.26)$ & 0.409 \\
\hline \multicolumn{7}{|l|}{ Department } \\
\hline Nursing ref & $82(52.9)$ & $73(47.1)$ & 1 & & & \\
\hline Pharmacy & $154(56.0)$ & $121(44.0)$ & $1.13(0.76-1.68)$ & 0.536 & $0.90(0.57-1.40)$ & 0.645 \\
\hline Medicine and Surgery & $270(61.9)$ & $166(38.1)$ & $1.44(1.00-2.09)$ & 0.050 & $1.31(0.86-2.01)$ & 0.205 \\
\hline \multicolumn{7}{|l|}{ Level of Education } \\
\hline Year 1 & $45(36.0)$ & $80(64.0)$ & 1 & & 1 & \\
\hline Year 2 & $56(43.4)$ & $73(56.6)$ & $1.36(0.82-2.26)$ & 0.228 & $1.31(0.78-2.19)$ & 0.305 \\
\hline Year 3 & $95(50.8)$ & $92(49.2)$ & $1.84(1.15-2.92)$ & $0.010^{*}$ & $1.75(1.09-2.80)$ & $0.021^{*}$ \\
\hline Year 4 & $134(71.7)$ & $53(28.3)$ & $4.49(2.77-7.29)$ & $0.001^{*}$ & $5.47(3.13-9.55)$ & $0.001^{*}$ \\
\hline Year 5 & $131(71.2)$ & $53(28.8)$ & $4.39(2.70-7.14)$ & $0.001^{*}$ & $5.42(2.94-9.97)$ & $0.001 *$ \\
\hline Year 6 (ref) & $45(83.3)$ & $9(16.7)$ & 3.98 (3.98-19.85) & $0.001^{*}$ & $9.29(3.75-22.96)$ & $0.001^{*}$ \\
\hline
\end{tabular}

$\mathrm{Cl}$ Confidence Interval, ${ }^{*}$ significance $p$ value $<0.05$

prescribing antibiotics in a non-controlled manner is not a good practice.

The findings from this study show antibiotics use in the management of malaria, malaria is one of the major health risks in tropical regions with high morbidity and death rates. Antimalarial drugs are the recommended medications for the chemoprophylaxis or treatment of malaria and not antibiotics. However, some antibiotics (tetracyclines and macrolides) are effective against malaria parasites [23]. Nonetheless, the inappropriate use of antibiotics in treating malaria could be promoting the emergence of bacterial resistance. Besides, more than half of the participants reported using antibiotics for the management of cough, sore throat, and the common cold. A systematic review on antibiotics use for the common cold and acute purulent rhinitis reported there is no benefit from antibiotics for the common cold, sore throat, and cough [24]. Common cold, sore throat, and cough are mostly viral infections, and antibiotics fight bacteria and not a virus. These results are comparable to outcomes in another study conducted in Rwanda, where $27 \%$ of the respondents had used antibiotics to treat common cold and sore throat [25].

It was observed in this study that the respondents' year of study and advanced age were significantly associated with the level of their knowledge of antimicrobial resistance. This might be a consequence of better handson experience and a greater degree of exposure to clinical practice as the students advance in their year of learning. Programs like the Student Industrial Work Experience Scheme (SIWES) and ward rounds which begin after the third year of study might also be responsible for the improved level of knowledge. These findings suggest that there is a need for timeliness of the efforts targeted at ensuring public education on antimicrobial resistance. This becomes necessary to steadily improve students' knowledge of antimicrobial stewardship, which will consequently lead to an increase in the value-added services to be offered by these future healthcare providers to the public. This will be especially useful in the context of patients' counseling on the awareness of antimicrobial resistance. Thus, the need to create awareness about antimicrobial stewardship among healthcare professionals in Nigeria has been emphasized in a recent study [26]. Furthermore, reinforcement of antimicrobial stewardship in all health facilities would create persistent awareness on antimicrobial resistance to healthcare professionals [27, 28].

\section{Limitations}

The results reported may be subject to recall bias, social appropriateness whereby the respondents either over or 
under-reported the use of antibiotics in the past 12 months. Furthermore, the inherent limitation of selfreporting may not be excluded. Future study may consider other possible socio-demographics such as living conditions and socio-economic status that may influence future healthcare professional knowledge and awareness in engaging in antimicrobial stewardship.

\section{Conclusions}

The healthcare students demonstrated a moderate knowledge of AMR, and their knowledge significantly varies across year of study. Our findings suggest enhancing the students' level of knowledge about the use of antibiotics might improve their antimicrobial stewardship. This study advocate for educational interventions to improve the knowledge and understanding of antimicrobial resistance among healthcare students and introducing the concept of AMR to healthcare students either via seminars/symposium or workshop starting at early years of study. Awareness campaign through media considering public health is also recommended. In addition, strict policies should be put in place to regulate the flow of antibiotics and to prevent the purchase of antibiotics without a medical prescription. This might be an approach to improve rational antimicrobial use and curb antimicrobial resistance.

\section{Abbreviations}

AMR: Antimicrobial Resistance; PPMV: Proprietary and Patent Medicine Vendors; SIWES: Student Industrial Work Experience Scheme

\section{Supplementary information}

The online version contains supplementary material available at https://doi. org/10.1186/s12909-021-02912-4

\section{Additional file 1.}

\section{Acknowledgements}

We would like to express our appreciation to the students who accepted to participate and dedicated their time to fill the questionnaire. This research is part of a larger study entitled "Self-Medication and Antibiotic Use Among Healthcare Students in a Nigerian University".

\section{Authors' contributions}

We declare that this work was done by the author(s) named in this article. Wuraola Akande-Sholabi (WAS) conceived the idea, WAS and Amen T Ajamu (ATA) designed the study, contributed in data acquisition, performed data analysis and interpretation. WAS drafted the manuscript. All authors contributed to the preparation of the manuscript, read and approved the final version.

\section{Funding}

No specific grant from any funding agency in the public, commercial or notfor-profit sector received in carrying out this study.

\section{Availability of data and material}

The datasets used and/or analysed during the current study are available from the corresponding author on reasonable request.

\section{Declarations}

\section{Ethics approval and consent to participate}

Ethics approval for the study was obtained from the joint University of Ibadan/University College Hospital Institutional Ethical Review Board with approval number UI/EC/19/0403. The principles of the Declaration of Helsinki were applied. Informed consent was obtained. Students consented to the use of the information for investigative purposes, and the analyses were based on data that do not contain information that could lead to the identification of the student. Only the consented participants within the study period were enrolled.

\section{Consent for publication}

Not applicable.

\section{Competing interests}

The authors declare that they have no competing interests.

Received: 9 March 2021 Accepted: 28 August 2021

Published online: 10 September 2021

\section{References}

1. Alhomoud F, Almahasnah R, Alhomoud FK. "You could lose when you misuse"-factors affecting over-the-counter sale of antibiotics in community pharmacies in Saudi Arabia: a qualitative study. BMC Health Services research. 2018: 18(1):1-9.

2. Umeokonkwo CD, Madubueze UC, Onah CK, Okedo-Alex IN, Adeke AS, Versporten A, Goossens $\mathrm{H}$, et al. Point prevalence survey of antimicrobial prescription in a tertiary hospital in south East Nigeria: a call for improved antibiotic stewardship. J Glob Antimicrob Resist. 2019;17:291-5.

3. Peche're JC. Patients' Interviews and Misuse of Antibiotics. Clin Infect Dis. 2001; 33(3):170-173. doi: https://doi.org/10.1086/321844.

4. Davies J, Davies D. Origins and evolution of antibiotic Resistance. Microbiol Mol Biol Rev [Internet]. 2010;74(3):417-33. https://doi.org/10.1128/MMBR. $00016-10$.

5. Okeke IN, Klugman KP, Bhutta ZA, Duse AG, Jenkins P, O'Brien TF, PablosMendez A, Laxminarayan R. Antimicrobial resistance in developing countries. Part II: strategies for containment. The Lancet infectious diseases. 2005;5(9):568-80.

6. Ayukekbong JA, Ntemgwa M, Atabe AN. The threat of antimicrobial resistance in developing countries: causes and control strategies. Antimicrobial Resistance \& Infection Control. 2017:6(1):47.

7. Cox JA, Vlieghe E, Mendelson M, Wertheim H, Ndegwa L, Villegas MV, et al. Antibiotic stewardship in low- and middle-income countries: the same but different? Clin Microbiol Infect. 2017;23(11):812-818

8. Scaioli G, Gualano MR, Gili R, Masucci S, Bert F, Siliquini R. Antibiotic use: cross-sectional survey assessing the knowledge, attitudes and practices amongst students of a school of medicine in Italy. PloS one. 2015:10(4): e0122476.

9. Arul PKC, Senthil KN, Ramesh J. Students' knowledge of antibiotics: a cross sectional study of students in Tamil Nadu. International Journal of Pharmacy and Pharmaceutical Science. 2011;3(1):232-3.

10. Auta A, Hadi MA, Oga E, Adewuyi EO, Abdu-Aguye SN, Adeloye D, et al. Global access to antibiotics without prescription in community pharmacies: A systematic review and meta-analysis. J Infect. 2019;78(1):8-18. doi: https:// doi.org/10.1016/j.jinf.2018.07.001

11. World Health Organization. The evolving threat of antimicrobial resistance: options for action. Geneva: World Health Organization; 2012. http://apps. who.int/iris/bitstream/10665/44812/1/9789241503181\$4eng.pdf. Accessed on 02 Oct 2017.

12. Sanya TE, Titilayo OF, Adisa R, Segun JS. Use of antibiotics among nonmedical students in a Nigerian university. Afr Health Sci. 2013;13(4):1149-55.

13. Istúriz RE, Carbon C. Antibiotic Use in Developing Countries. Infect Control Hosp Epidemiol. 2000; 21.6: 394-397

14. Yamane T. Statistics, an introductory analysis. 2nd ed. New York: Harper and Rao. 1967; 886.

15. Bloom BS, ed. Taxonomy of Educational Objectives: The Classification of Educational Goals, Handbook I, Cognitive Domain. London: Longmans, Green; 1956

16. Akande-Sholabi W, Adisa, R, llesanmi, OS, Bello EA. Extent of misuse and dependence of codeine-containing products among medical and pharmacy 
students in a Nigerian University. BMC Public Health. 2019; 19:1709. doi: https://doi.org/10.1186/s12889-019-8074-5

17. Akande-Sholabi W, Ogundipe FS, Adisa R. Pharmacists' knowledge and counselling on fall risk increasing drugs in a tertiary teaching hospital in Nigeria. BMC Health Serv Res. 2020; 20:259

18. Azevedo MM, Pinheiro C, Yaphe J, Baltazar F. Portuguese students' knowledge of antibiotics: a cross-sectional study of secondary school and university students in Braga. BMC Public Health. 2009;9(1):359.

19. Ahmad A, Khan MU, Patel I, Maharaj S, Pandey S, Dhingra S. Knowledge, attitude and practice of B.Sc. Pharmacy students about antibiotics in Trinidad and Tobago. J Res Pharmacy Prac. 2015:4(1):37.

20. Akande-Sholabi W, Ajamu AT, Adisa R. Prevalence, Knowledge and Perception of Self-medication Practice among Undergraduate Healthcare Students. Journal of Pharmaceutical Policy and Practice. 2021; 14:49. doi: https://doi.org/10.1186/s40545-021-00331-w

21. Brieger WR, Osamor PE, Salami KK, Oladepo O, Otusanya SA. Interactions between patent medicine vendors and customers in urban and rural Nigeria. Health Policy Plan 2004;19: 177-182. PMID: 15070866

22. Uzochukwu BSC, Onwujekwe OE, Okwusa C, Ibe OP. Patent medicine dealers and irrational use of medicines in children: the economic cost and implications for reducing childhood mortality in southeast Nigeria. PloS One 2014;9: e91667. doi: https://doi.org/10.1371/journal.pone.0091667 PMID: 24621618

23. Gaillard T, Dormoi J, Madamet M, Pradines B. Macrolides and associated antibiotics based on similar mechanism of action like lincosamides in malaria. Malar J. 2016;15:85

24. Kenealy T, Arroll B. Antibiotics for the common cold and acute purulent rhinitis. Cochrane Database of Syst Rev. 2013;(Issue 6):CD000247. https://doi. org/10.1002/14651858.CD000247.pub3.

25. Nisabwe L, Brice H, Umuhire MC, Gwira O, Harelimana JD, Nzeyimana Z, et al. Knowledge and attitudes towards antibiotic use and resistance among undergraduate healthcare students at University of Rwanda Journal of Pharmaceutical Policy and Practice. 2020; 13:7 https://doi.org/10.1186/s4054 5-020-00207-5

26. Abubakar U. Antibiotic use among hospitalized patients in northern Nigeria: a multicenter point-prevalence survey. BMC Infectious Diseases. 2020;20:86 https://doi.org/10.1186/s 12879-020-4815-4

27. Kalungia AC, Mwambula H, Munkombwe D, Marshall S, Schellack N, May C, et al. Antimicrobial stewardship knowledge and perception among physicians and pharmacists at leading tertiary teaching hospitals in Zambia: implications for future policy and practice. J Chemother. 2019;31(7-8):37887. https://doi.org/10.1080/1120009X.2019.1622293.

28. Fadare JO, Ogunleye O, lliyasu G, Adeoti A, Schellack N, Engler D, et al. Status of antimicrobial stewardship programmes in Nigerian tertiary healthcare facilities: Findings and implications. J Glob Antimicrob Resist. 2019;17:132-6. https://doi.org/10.1016/j.jgar.2018.11.025.

\section{Publisher's Note}

Springer Nature remains neutral with regard to jurisdictional claims in published maps and institutional affiliations.

Ready to submit your research? Choose BMC and benefit from:

- fast, convenient online submission

- thorough peer review by experienced researchers in your field

- rapid publication on acceptance

- support for research data, including large and complex data types

- gold Open Access which fosters wider collaboration and increased citations

- maximum visibility for your research: over $100 \mathrm{M}$ website views per year

At $\mathrm{BMC}$, research is always in progress.

Learn more biomedcentral.com/submissions 